\title{
PEMBINAAN DAN PENERAPAN STRATEGI PEMASARAN MELALUI MEDIA SOSIAL PADA HOME INDUSTRI MASYARAKAT TANJUNG GUNDAP
}

\author{
Nora Pitri Nainggolan*1, Intan Utnasari ${ }^{2}$ \\ Universitas Putera Batam \\ *e-mail: noranainggolan.nn@gmail.com¹, intanutna88@gmail.com²
}

\begin{abstract}
ABSTRAK
Ditengah-tengah kemajuan teknologi pada jaman sekarang ini masih terdapat masyarakat yang berada jauh dari kemajuan teknologi. Masyarakat ini merupakan suku asli yang berada di pesisir laut dengan menggantungkan hidupnya dari laut yaitu dengan menjadi nelayan. Salah satu suku laut yang masih tersisa di pesisir kota Batam adalah suku laut Tanjung Gundap. Oleh karena itu pengabdian pada kali ini dilakukan di Tanjung Gundap. Tanjung Gundap terletak di Kepulauan Riau, Kabupaten Kota Batam, Kecamatan Sagulung, Kelurahan Tembesi. Pengabdian ini diberikan kepada masyarakat Tanjung Gundap yang berada di RW 01/ RT 02. Berdasarkan survey yang dilakukan oleh Tim Pengabdi pada hari Minggu tanggal 29 Juli 2018 dan hari Selasa tanggal 31 Juli 2018.
\end{abstract}

Kata kunci: Kemajuan Teknologi, Masyarakat, Suku Laut. 


\section{PENDAHULUAN}

Ditengah-tengah kemajuan teknologi pada jaman sekarang ini masih terdapat masyarakat yang berada jauh dari kemajuan teknologi. Masyarakat ini merupakan suku asli yang berada di pesisir laut dengan menggantungkan hidupnya dari laut yaitu dengan menjadi nelayan. Salah satu suku laut yang masih tersisa di pesisir kota Batam adalah suku laut Tanjung Gundap. Oleh karena itu pengabdian pada kali ini dilakukan di Tanjung Gundap. Tanjung Gundap terletak di Kepulauan Riau, Kabupaten Kota Batam, Kecamatan Sagulung, Kelurahan Tembesi. Pengabdian ini diberikan kepada masyarakat Tanjung Gundap yang berada di RW 01/RT 02.

Masyarakat Tanjung Gundap merupakan masyarakat kecil yang hidup di pesisir kota Batam. Masyarakat Tanjung Gundap rata-rata hidup sebagai nelayan yang sangat menggantungkan hidup mereka pada hasil tangkapan laut. Jika melihat dari sejarah suku laut, dahulu mereka tinggal di perahu dan tinggal berpindah-pindah. Dari segi tempat tinggal kini mereka telah mengalami kemajuan dengan tempat tinggal yang menetap. Meskipun letaknya berdekatan dengan Kota Batam, namun perkembangan di pulau ini masih tergolong lambat sangat berbeda jauh dengan perkembangan di Kota Batam. Berdasarkan survey yang dilakukan oleh Tim Pengabdi pada hari Minggu tanggal 29 Juli 2018 dan hari Selasa tanggal 31 Juli 2018, terlihat penduduk di Tanjung Gundap masih sangat sederhana, hal ini terlihat dari rumah-rumah penduduk,mereka membangun rumah panggung sebagai tempat tinggal mereka yang terletak di pesisir laut. Lingkungan tempat tinggal yang masih kotor dan jauh dari lingkungan yang sehat. Kehidupan ekonomi mereka masih belum layak dikarenakan sangat bergantung pada hasil laut. Mata pencaharian utama masyarakat Tanjung Gundap adalah sebagai nelayan, hampir $90 \%$ warganya mencari pendapatan dengan melaut. Adapun tambahan pendapatan yang dilakukan adalah dengan memproduksi kayu bakar untuk dijual dan mengolah ikan hasil tangkapan menjadi bentuk cemilan (kerupuk/ keripik) untuk dijual kepada masyarakat di Kota Batam. Di Tanjung Gundap telah dibangun sekolah walau masih terbatas jumlahnya, dan pendidikan masih minim. Untuk listrik masyarakat sudah mendapatannya walau dibatasi waktu penerangannya. Untuk air bersih mereka hanya memiliki satu sumur umum dengan mata air yang kecil. Sehingga dapat dikatakan air bersih untuk masyarakat Tanjung Gundap terbatas jumlahnya. 
Dengan melihat situasi yang dihadapi masyarakat Tanjung Gundap maka Tim pengabdi merasa perlu membantu perbaikan ekonomi agar mereka dapat hidup lebih layak. Pengabdian yang dilakukan dengan memberikan pembinaan kepada masyarakat tentang bagaimana mereka dapat memasarkan cemilan (kerupuk/keripik) yang telah mereka olah dan dapat dijual lebih maksimal dengan memanfaatkan media sosial agar dapat menjangkau konsumen lebih luas.

Pemasaran adalah aktivitas, serangkaian institusi, \& proses menciptakan, mengomunikasikan, menyampaikan, \& mempertukarkan tawaran yg bernilai bagi pelanggan, klien, mitra, \& warga umum. Pemasaran dimulai menggunakan pemenuhan kebutuhan insan yg lalu bertumbuh sebagai harapan insan. Strategi pemasaran adalah hal yg sangat krusial bagi perusahaan pada mana taktik pemasaran adalah suatu cara mencapai tujuan berdasarkan sebuah perusahaan, karna potensi buat menjual proposisi terbatas dalam jumlah orang yg mengetahui hal tersebut. Sehingga pada menjalankan bisnis mini khususnya dibutuhkan adanya pengembangan melalui taktik pemasarannya. Lantaran dalam ketika syarat kritis justru bisnis kecillah yg sanggup menaruh pertumbuhan terhadap pendapatan warga .

Masyarakat juga perlu mendapatkan pembinaan penggunaan media sosial untuk membantu penjualan produk home industry mereka. Media sosial adalah media yang didesain untuk memperluas interaksi sosial manusia dengan menggunakan internet dan teknologi web. Media sosial berhasil mentransformasi praktik komunikasi searah media siaran dari satu institusi media ke banyak audience (one to many) kedalam praktik komunikasi dialogis antara banyak audience (many to many).

Mengingat begitu pentingnya pemahaman strategi pemasaran dan penggunaan media sosial, maka tim pengabdi berencana akan memberikan pembinaan dengan judul "Pembinaan dan Penerapan Strategi Pemasaran Melalui Media Sosial pada Home Industri Masyarakat Tanjung Gundap". Tentunya kegiatan pengabdian ini memerlukan dukungan dan bantuan dari segenap pihak, baik sivitas akademika Fakultas Ekonomi Universitas Putera Batam maupun pihak lain atas dasar kebersamaan. Dukungan moral, dan materi akan sangat membantu program ini.

Adapun permasalahan yang ditemui saat melakukan survey kelokasi pengabdian adalah:

1. Keadaan ekonomi masyarakat yang belum layak

2. Lingkungan tempat tinggal yang kotor dan kurang sehat

3. Sulitnya mendapatkan air bersih

4. Pendidikan yang minim 
5. Pengetahuan yang terbatas dalam mengelola dan memasarkan produk home industry

6. Pengetahuan yang terbatas dalam penggunaan teknologi

\section{METODE}

Melihat permasalahan yang dihadapi oleh masyarakat Tanjung Gundap, maka berikut solusi yang ditawarkan dari kegiatan pengabdian ini:

1. Terkait dengan permasalahan mengenai keadaan ekonomi yang masih belum layak. Maka solusi yang ditawarkan adalah menciptakan lapangan kerja baru melalui kegiatan industri rumahan.

2. Terkait dengan masalah pendidikan yang minim dan pengetahuan yang terbatas dalam penggunaan teknologi. Maka solusi yang ditawarkan adalah memberikan pembinaan mengenai penerapan strategi pemasaran yang efisien dan efektif dan melatih dalam pengunaan media sosial sebagai sarana dalam memasarkan produk hasil home industry.

\section{HASIL DAN PEMBAHASAN}

Berdasarkan pembinaan yang telah dilakukan pada masyarakat Tanjung Gundap RT.02/ RW.01 telah dapat memberikan dampak yang positif kepada para peserta dan juga kepada tim dosen yang melakukan pembinaan, secara lebih rinci hasil yang dicapai dari pelaksanaan pembinaan tersebut dapat diuraikan antara lain sebagai berikut:

1.Terjalinnya kerjasama antara Universistas Putera Batam dengan masyarakat Tanjung Gundap RT.02/ RW.01 secara berkelanjutan.

2.Peserta diberikan pembinaan mengenai strategi pemasaran produk home industry yang mereka miliki dan membina tentang bagaimana menggunakan media sosial untuk memasarkan produk mereka.

3.Menambah wawasan masyarakat tentang bagaimana pemasaran yang efektif dan bagaimana memanfaatkan media sosial bagi pemasaran produk.

4.Mengembangkan dan berbagi ilmu pengetahuan kepada masyarakat yang ada, khususnya masyarakat Tanjung Gundap RT.02/ RW.01.

Selama memberikan pembinaan mengenai strategi pemasaran dan penggunaan media sosial masyarakat sangat antusias dan bersemangat mengikuti kegiatan. Materi pembinaan dari hari pertama sampai dengan hari kedua yang disampaikan sewaktu pengabdian kepada masyarakat Tanjung Gundap RT.02/ RW.01 yaitu:

\section{Strategi Pemasaran}

Untuk menaikkan daya produksi, suatu bisnis tentunya harus mempunyai taktik pemasaran supaya mempunyai daya tawar dan bisa menarik perhatian konsumen. Pada 
dasarnya taktik pemasaran yg baik, bagi pelaku usaha bisa menaikkan nilai tambah suatu produk. Hal ini krusial buat dilakukan mengingat persaingan usaha dalam era kini semakin ketat. Semua bisnis yg memperlihatkan produk, nir terkecuali bisnis akbar juga kecil, wajib mempunyai taktik pemasaran supaya produk yg dimiliki mempunyai daya jual yg lebih menurut pesaingnya. Kemudian, hal yg perlu diperhatikan dalam termin selanjutnya merupakan tetapkan target pemasarannya. Untuk itu, perlu dibuat suatu Marketing Strategy and Planning atau Strategi \& Perencanaan Pemasaran. Yang sebagai masalah merupakan apakah setiap bisnis mempunyai asal daya insan menggunakan mempunyai kapasitas yg mumpuni, baik buat menemukan taktik pemasaran yg sempurna dan mengimplementasikannya. Dalam menyikapi pertanyaan ini, bukanlah jawaban ya atau nir yg perlu diperhatikan, melainkan setiap bisnis wajib berperan aktif supaya bisa mempunyai pengetahuan dan kecakapan pada merumuskan perencanaan dan taktik pemasaran.

\section{Media Sosial}

\section{Sarana promosi yang sangat efektif}

Media online juga diberikan ruang terbesar bagi perusahaan untuk masuk dan menginformasikan produk atau layanan yang menciptakan masyarakat. Anda dapat mempromosikan produk atau layanan ini melalui Internet melalui halaman web, iklan online, milis, jejaring sosial, blog, komunitas bisnis, dan sebagainya. Dengan jangkauan pasar yang tidak terbatas, Anda memiliki peluang yang lebih baik untuk menarik sebanyak mungkin konsumen.

\section{Cara yang tepat untuk membangun merek yang kuat}

Semakin banyak rutinitas Anda mempromosikan produk atau layanan online, semakin tidak menutup kemungkinan bahwa citra merek yang Anda miliki mungkin segera bangun dengan kuat. Dan semakin kuat gambaran merek yang terbentuk, sehingga kepercayaan konsumen akan mulai membangun dan dapat dipastikan bahwa bisnis Anda tidak kalah bersaing dengan perusahaan lain di pasar.

\section{Menyederhanakan riset pasar}

Peran media online tidak kalah pentingnya sebagai sarana berbisnis untuk riset pasar. Melalui informasi dari internet, Anda dapat mengetahui berapa banyak manfaat yang Anda 
miliki, berapa banyak minat pasar yang Anda miliki, dan menemukan informasi tentang siapa pesaing utama bisnis Anda.

Hasil pencarian yang Anda terima di pasar dapat digunakan sebagai pertimbangan sebelum menentukan strategi bisnis Anda di masa depan.

4. Menjadi jembatan bagi bisnis dan konsumen

Dengan Internet, Anda dapat berkomunikasi dengan konsumen dan pelanggan potensial Anda di berbagai belahan dunia. Misalnya, melalui situs jejaring sosial, email, Yahoo Messenger, Skype, chat, dan sebagainya.

Suksesnya kegiatan pembinaan yang diberikan kepada masyarakat Tanjung Gundap RT.02/ RW.01, telah menjadi kebanggaan tersendiri bagi tim pengabdi. Beberapa hal yang dilaksanakan oleh tim dosen untuk menyukseskan kegiatan pembinaan secara garis besar dapat dijelaskan sebagai berikut:

1. Survey ke lokasi pengabdian dilaksanakan

2. Mencari materi pembinaan yang akan dilakukan

3. Membuat proposal pengabdian

4. Mengumpulkan dana untuk acara pengabdian seperti biaya mencetak spanduk, cetak materi dan konsumsi

5. Mencetak spanduk

6. Belanja untuk konsumsi selama acara pengabdian

7. Melakukan kegiatan pengabdian

Kegiatan pengabdian yang dilaksanakan di masyarakat Tanjung Gundap RT.02/ RW.01 memberikan respon positif dan dapat diterima dengan baik oleh masyarakat. masyarakat antusias mengikuti kegiatan pembinaan yang pengabdi lakukan. Dengan dilaksanakannya kegiatan pembinaan ini, pemahaman masyarakat semakin bertambah dan semakin bersemangat dalam membuat produk home industry seperti kerupuk gongong, kerupuk ikan, kerupuk tiram, keripik ubi dan bersemangat memasarkannya secara luas melalui penggunaan media sosial. Masyarakat sebagian besar telah memiliki smartphone namun tidak memahami bahwa media sosial yang mereka miliki dapat juga dijadikan alat promosi bagi produk yang telah mereka buat. Sehingga dapat menjangkau konsumen yang lebih luas lagi untuk memperbaiki ekonomi keluarga. 
Tabel 1. Metode Pelaksanaan

\begin{tabular}{|c|c|c|c|c|}
\hline Pertemuan & Permasalahan & Solusi & Metode & Pemateri \\
\hline 1 & $\begin{array}{lr}\text { Pendidikan } & \text { yang } \\
\text { minim } & \text { tentang } \\
\text { pemasaran } & \text { hasil } \\
\text { home industry }\end{array}$ & $\begin{array}{l}\text { Memberikan } \\
\text { pembinaan tentang } \\
\text { bagaimana } \\
\text { penerapan strategi } \\
\text { pemasaran terhadap } \\
\text { hasil home industry } \\
\text { dan menggiatkan } \\
\text { home industry yang } \\
\text { sudah ada }\end{array}$ & $\begin{array}{l}\text { Pembina } \\
\text { an dan } \\
\text { Diskusi }\end{array}$ & Ketua \\
\hline 2 & $\begin{array}{ll}\text { Pengetahuan } & \text { yang } \\
\text { terbatas } & \text { dalam } \\
\text { penggunaan } & \text { media } \\
\text { social } & \end{array}$ & $\begin{array}{l}\text { Memberikan } \\
\text { pembinaan dan } \\
\text { mengajarkan } \\
\text { bagaimana } \\
\text { penggunaan media } \\
\text { sosial yang } \\
\text { bermanfaat untuk } \\
\text { memaksimalkan } \\
\text { penjualan hasil home } \\
\text { industry }\end{array}$ & $\begin{array}{l}\text { Pembina } \\
\text { an dan } \\
\text { Diskusi }\end{array}$ & Anggota \\
\hline
\end{tabular}

Tabel 2. Evaluasi dalam Pembinaan

\begin{tabular}{|c|c|c|}
\hline & & \\
\hline $\begin{array}{l}\text { Memberikan pembinaan } \\
\text { penerapan } \\
\text { pemasaran bagi produk } \\
\text { home industry }\end{array}$ & $\begin{array}{l}\text { Pemahaman dan } \\
\text { Pelaksanaan Strategi } \\
\text { Pemasaran dalam mengelola } \\
\text { dan memasarkan produk } \\
\text { home industry }\end{array}$ & $\begin{array}{l}\text { Mampu melaksanakan tiap } \\
\text { tahapan dari strategi } \\
\text { pemasaran dengan efisien } \\
\text { dan efektif }\end{array}$ \\
\hline $\begin{array}{l}\text { Memberikan pembinaan } \\
\text { penggunaan media sosial } \\
\text { dalam memasarkan produk } \\
\text { home industry }\end{array}$ & $\begin{array}{l}\text { Pemahaman } \\
\text { Pelaksanaan Penggunaan } \\
\text { media sosial dalam } \\
\text { memasarkan produk home } \\
\text { industry }\end{array}$ & \begin{tabular}{lr} 
Mampu & \multicolumn{2}{c}{ membuatakun } \\
media sosial dan \\
memasarkan hasil home \\
industry melalui media \\
sosial tersebut
\end{tabular} \\
\hline
\end{tabular}




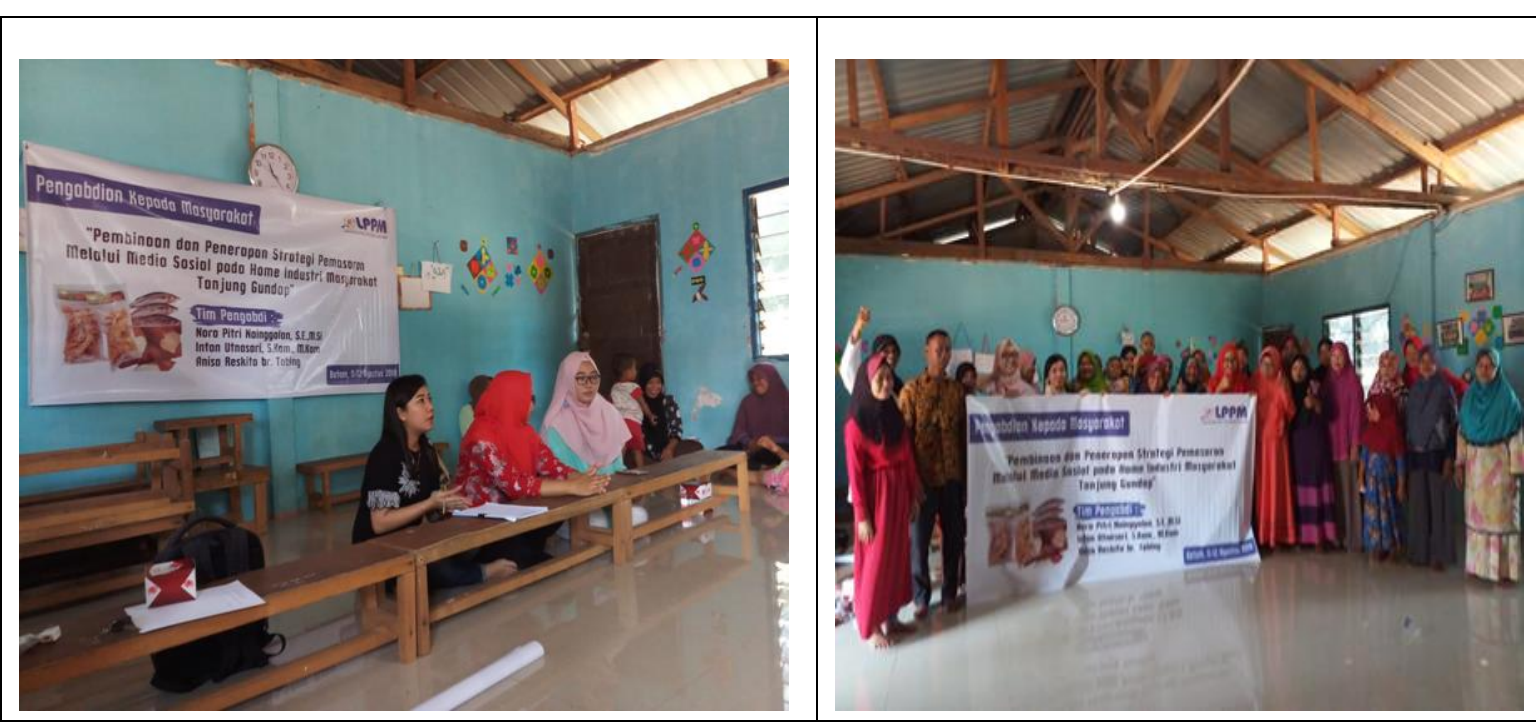

Gambar 1. Pengabdi Memberikan Pembinaan Tanjung Gundap

Gambar 2. Bersama Masyarakat

\section{KESIMPULAN}

Berdasarkan pembahasan pembinaan yang dilakukan pada masyarakat Tanjung Gundap RT.02/ RW.01, maka disimpulkan sebagai berikut:

1. Peserta memahami mengenai strategi pemasaran dan penggunaan media sosial.

2. Peserta pengabdian mampu menggunakan media sosial terkait dengan materi pengabdian yang telah diberikan.

Berdasarkan simpulan di atas, maka disarankan sebagai berikut:

1. Masyarakat Tanjung Gundap RT.02/ RW.01 disarankan dapat meningkatkan pemahaman dan semangat mereka untuk memasarkan produk lebih giat lagi.

2. Mencari sebanyak-banyaknya peluang kerjasama untuk memasarkan produk

3. Produk home industry yang mereka miliki segera diuruskan label hala dan BPOM nya agar produk dapat dipasarkan secara nasional.

4. Masyarakat juga diharapkan mampu mengelola media sosial yang mereka miliki sebagai alat pemasaran secara online untuk menjangkau konsumen yang lebih luas. 


\section{DAFTAR PUSTAKA}

Philip Kotler \& Gary Armstrong,"Prinsip-prinsip Pemasaran”, 2008, edisi 12. Penerbit Erlangga Jakarta.

https://media.neliti.com/media/publications/79987-ID-sejarah-perkembangan-suku-laut-ditanjun.pdf

http://www.artikelsiana.com/2017/09/pengertian-media-sosial-fungsi.html\# file:///C:/Users/Downloads/Pembinaan_dan_Penerapan_Strategi_Pemasar.pdf https://www.academia.edu/30094321/Pembinaan_dan_Penerapan_Strategi_Pemasaran_Melal ui_Media_Sosial_pada_Home_Industri_Randang_Awak_Juo 